https://doi.org/10.38129/Ann.Yur.Ist.2020.4.2.58

УДК 369.221.3: 331.483.7:34.08(349.23/24)

\title{
РОЗВИТОК МЕДИЧНОГО ПРАВА НА ЗЕМЛЯХ ЗАХІДНОЇ УКРАЇНИ НА ПОЧАТКУ ХХ СТ. (АСПЕКТ СТРАХУВАННЯ)
}

\author{
АРСЕН ТЕРОВАНЕСОВ (Харків, Україна) *
}

На сьогоденному етапі розвитку суверенної Української Держави відбувається реформування галузі охорони здоров' я. У зв' язку з цим нагальним завданням $\epsilon$ удосконалення права громадян на медичну допомогу та удосконалення правовідносин між пацієнтом і медичним працівником. Такі перетворення мають дозволити громадянам реалізовувати комплекс прав i свобод, що передбачені Конституцією України та приведуть до розвитку демократичної держави та громадянського суспільства. В такому контексті страхування здоров'я виступає невід'ємною гарантією дотримання права на медичну допомогу.

Вітчизняне медичне законодавство, включаючи страхування, розвинулось впродовж XX ст. При цьому соціальне законодавство західноукраїнських земель, у порівнянні із землями Східної України, було більш розгалуженим, оскільки мало вплив декількох європейських держав. Тому, вивчення становлення основ страхування, в контексті медичного права, на землях Західної України є важливим та актуальним.

Територія Галичини, Буковини і Закарпаття на початку XX ст. знаходилася під владою Австро-Угорської Імперії, а згодом стала частиною новоствореної Польської та Чехословацької республік і Королівства Румунії. Кожна 3 цих держав мала окрему систему законодавства. У часи перебування західноукраїнських земель під юрисдикцією іноземних держав відбулось реформування соціальної сфери та прийняття нормативних актів, які закріплювали права працівників підприємств, як пацієнтів. 3 цього часу з'явилися передумови, які у сукупності із нормами соціального законодавства, правовими актами, що регулюють відносини страхування, трансформувалися у медичне право.

М. Бреян вважає, що варто охарактеризувати існування медичного права лише на зародковому етапі, у зв'язку зі становленням нових специфічних 
суспільних відносин та прийняттям для їх регулювання спеціального законодавства, що виходить за межі предмета регулювання традиційно існуючих галузей законодавства 1 .

До предмета медичного права належать відносини, пов'язані із медичною діялністю. Страхування здоров'я осіб у такому випадку виступає послугою, яку надають лікувальні установи.

Деякі вчені до основних завдань науки медичного права відносять пошук правових шляхів удосконалення медичного страхування². У даному випадку варто вказати, що особливістю медичного страхування є приналежність до деяких правових інститутів, починаючи із соціального забезпечення населення як сукупності цивільно-правових норм і закінчуючи адміністративними правовідносинами між органами державної влади та лікувальними установами.

О. Процевський вважає, що за умов розвитку ринкової економіки фактично склалися i функціонують нові галузі права, зокрема судове, медичне, ювенальне, охоронне, транспортне тощо ${ }^{3}$. Слід вказати, що засади ринкової економіки почали формуватися наприкінці XIX ст., коли великими темпами стало розвиватись промислове виробництво, що привело до необхідності нормативно закріпити права робітників, серед яких права на працю, на відпочинок, на медичну допомогу. Тому, договори страхування, які укладалися на підприємствах, гарантували робітникам надання якісного лікування у разі настання нещасного випадку на виробництві. У зв'язку з цим, можна стверджувати, що страхування здоров'я $\epsilon$ невід'ємною частиною відносин медичного права. Розвиток медичного страхування був пов'язаний із становленням капіталістичних відносин у країнах Європи.

У другій половині XVIII ст. відбувся розпад Речі Посполитої, і територія Галичини та Буковини опинилась під владою Австрії, яка згодом, уклавши угоду із Угорщиною, перетворилася на дуалістичну монархію на чолі із

1 Бреян Т. А. Наукові погляди на місце медичного права в системі права України [Текст] / Т. А. Бреян / / Медичне право України: проблеми становлення та розвитку: матеріали I Всеукр. наук.-практич. конф. 19-20.04.2007, Львів. - 2007. - С. 36.

2 Радиш Я. Ф. Медичне право в системі права України: стан і перспективи розвитку [Текст] / Я. Ф. Радиш, Ю. В. Вороненко / / Український медичний часопис. - 2006. № 5 (55). - С. 8.

3 Процевський О. І. Щодо системи трудового права України [Текст] / О. I. Процевський // Тенденції розвитку науки трудового права та права соціального забезпечення: зб. наук. праць. Матеріали I Міжнар. наук.-практич. конф. 25-26 квітня 2013 р., Київ. - С. 338. 
династією Габсбургів ${ }^{4}$. Конституційно закріпивши державний лад, влада почала реформу соціальної сфери. Зміни були пов'язані із економічним занепадом власних територій, населення яких вимагало захисту своїх прав із метою забезпечення фінансового добробуту. Слід зазначити, що АвстроУгорщина, переважно аграрна країна, мала свої родючі землі, які були розташовані на території Галичини, та у повному обсязі не використовувалися ${ }^{5}$. Це було пов'язано із непродуманою політикою, яку провадив австрійський уряд на даній території. Крім того, потрібно звернути увагу на тенденції реформування, що на той час існували в Европі. Починаючи iз другої половини XIX ст., провідні країни світу почали розробляти законодавство про соціальне страхування працівників підприємств, яке передбачало обов' язкове надання медичної допомоги.

Так, Німеччина впровадила страхування від нещасних випадків у 80-х рр. XIX ст. шляхом відкриття фондів, які розвивалися під контролем роботодавців та були направлені на підвищення добробуту робітників. Держава створювала умови для функціонування такої системи нагляду за дотриманням законності 6 . Дана модель страхування була обов'язковою для працівників підприємств та сприяла розв'язанню проблем соціального забезпечення населення та розвитку галузі медичного права.

Разом із тим, законодавці звертали увагу на країни, де страхування мало змішаний характер. У Франції, наприклад, починаючи із 1850-х рр. було впроваджено страхування робітників усіх сфер, які були учасниками фондів взаємодопомоги ${ }^{7}$. Така система дозволяла працівникам укладати угоди на сприятливих умовах із відповідним товариством. Але, незважаючи на свободу дій, надаваних фондам, існувала ієрархічна система, яка знаходилася під контролем держави ${ }^{8}$. Це дозволяло уникати порушень із боку як страхових

4 Тейлор А. Габсбургзька монархія 1809-1918: історія Австрійської імперії та АвстроУгорщини [Текст] / А. Дж. П. Тейлор. - Львів : ВНТЛ-Класика, 2002. - с. 133.

5 Злупко С. Економічна думка на Україні: нариси історії економічної думки на західноукраїнських землях у другій половині XIX ст. [Текст] / С. Злупко. - Львів : Видво Львівськ. ун-ту, 1969. С. 31.

6 Андрушків I. П. Загальні підходи до міжнародного медичного страхування в окремих країнах [Текст] / І. П. Андрушків, К. А. Львівська / / Науковий вісник НЛТУ України: - зб. наук.-техн. праць. - 2010. - Вип. 20.13 - С. 172.

7 Социальное страхование в Европе согласно современому законодательству различных государств / С Страховое обозрение. - 1912. - Ноябрь. - С. 764.

8 Медичне страхування та його особливості в зарубіжних країнах // Фінансовий ринок України. - 2008. - № 4 (54). - С. 34. 
компаній, так і підприємств, оскільки роботодавці були зацікавлені у зменшенні витрат на соціальні виплати працівникам. У Франції набула поширення обов'язковість страхування робітників гірничої сфери. Це пов'язано із важкими умовами праці, які призводили до великої кількості нещасних випадків, що трапляються на підприємствах видобувної промисловості. Тому держава намагалася надати працівникам гарантії грошової та медичної допомоги.

На той час в Європі існували країни, які впроваджували виключно добровільну форму страхування. Так, в Іспанії була розвинута система, яка на початку XX ст. відповідала вимогам суспільства. Цікавим уявляється той факт, що компанії мали право рекламувати свої послуги та пропагувати діяльність на заводах та в установах, залучаючи робітників до процесу укладення угод9. Така форма страхування задовольняла велику кількість населення, що було сприятливою формою для робітників важких підприємств та інших сфер суспільства. Австро-Угорщина, із метою розробки системи соціального страхування, намагалась віднайти свій шлях для реформування, поєднуючи досвід провідних країн Європи із економічними особливостями власної дуалістичної держави.

Королівство Галичина і Володимерія, герцогство Буковина і Закарпаття не мали достатнього промислового потенціалу, на відміну від інших земель Австро-Угорщини. Західноукраїнські землі містили корисні копалини, такі як залізо, мідь тощо. Крім того, ці території відрізнялися родючими грунтами, що дозволяло розвивати сільське господарство.

Раціональне використання природних ресурсів мало привести до побудови індустріально-аграрної держави із розвиненої економікою, яка успішно реалізувала зобов'язання із соціального забезпечення громадян. Натомість, монопольне панування польської шляхти призвело до занепаду цих земель.

К. Баладиженко звертає увагу, щуо знищення лісів, виснаження грунту та відмова від прогресивних форм ведення землеробства вплинула на зростання бідності селян 10. Із думкою автора можна погодитись, оскільки райони західноукраїнських земель були сировинною складовою австрійської промисловості. Це призводило до зростання дешевої робочої сили, яка складалася переважно із місцевого населення. У зв'язку із цим, правлячий клас імперії не бачив сенсу в економічному підйомі даних територій. Така політика

${ }_{9}^{9}$ Страхование рабочих в Испании / / Страховое обозрение. - 1912. - Февраль. - С. 89. 10 Баладыженко К. Иллюстрированная Исторія Галичины въ краткихъ очеркахъ / К. Баладыженко. - Петроградъ: Типографія Бр. В. и И. Линникъ: Петроградъ, 1915. С. 99. 
негативно впливала на соціальний стан жителів та викликала незадоволення серед мешканців краю.

Початок XX ст. характеризується зростанням страйкових настроїв по всій Европі. Ідеї боротьби за права робітників та селян, викликані неналежними умовами праці, були обумовлені промисловим прогресом та потребували докорінних змін в усіх сферах суспільного життя. О. Жерноклеєв зазначає, що Галицький регіон становив відсталу $b$ економічному відношенні аграрну провіниію Австро-Угорщини із численними залишками фееоалізму ${ }^{11}$. Тому перед урядом постали завдання щодо скорішого реформування економічної і соціальної сфери, оскільки зростаюче незадоволення робітничого класу здійснювало тиск на владу, що могло призвести до повалення державного устрою.

Враховуючи той факт, щзо територія держави фрактично була поділена між промисловиями та землевласниками, добробут жителів залежав від волі власника певного господарства. Неможливість працювати та отримувати платню, разом із усвідомленістю власного безправ' я, вплинули на втрату населенням довіри до правлячої династії. Це змусило розпочати реформи промислової сфери, які потягнули за собою зміни в інших галузях господарства.

Ще одним фактором, який вплинув на впровадження медичного страхування, є прокладання у XIX ст. щляхів сполучення.

Е. Реклю називає серед важливих економічних перетворень, які здійснюються у той час в Галичині, побудову залізниць ${ }^{12}$. Подібні урядові перетворення вимагали не тільки значних фінансових витрат, але й використання робочої сили. Працівники державних залізниць, у свою чергу, були зацікавлені у створенні належних умов праці, включаючи не тільки високу відповідну плату та пенсійне забезпечення, але й належну медичну допомогу. Тобто, на відміну від земель Центральної та Східної України, Галичина, Буковина i Закарпаття мали інші передумови впровадження соціального страхування. На півдні сучасної України було сконцентровано велику кількість металургійних та видобувних фабрик, робітники яких виборювали собі право на належну медичну допомогу. Обов'язкове страхування розповсюджувалося на працівників важких підприємств. Але уряд

11 Жерноклеєв О. Українська соціал-демократія в Галичині: нарис історії (1899-1918) [Текст] / О. Жерноклеєв. - [2-е вид., доп.]. - К. : Основні цінності, 2000. С. 22.

12 Реклю Э. Народы и страны Западной Европы / Э. Реклю // Переводъ съ французскаго подъ редакцией и съ дополненіями Н. К. Лебедева. - М. : Типографія Т-ва И. Д. Сытина, 1915. - Т. V. Австро-Венгрія. - с. 103. 
Австро-Угорщини, при запроваджені медичного страхування, мав забезпечити робітників інших сфер.

По-перше, наявність сільськогосподарських районів обумовила соціальне забезпечення селян.

По-друге, видобуток корисних копалин вимагав залучення робітників, що також вплинуло на страхування працівників промислових підприємств.

По-третє, працівники державної залізниці заявляли про необхідність покращення умов праці, що також спричинило перетворення в соціальній галузі.

Схожою рисою у реформуванні системи медичної допомоги усіх країн Европи стало вивчення досвіду Німеччини, яка була новатором у сфері страхування. Як вказує I. Фуртак, Королівство Галичина і Володимирія i герцогство Буковина та Закарпаття у складі Австро-Угорської імперії впровадили обов'язкове медичне страхування за моделлю Бісмарка через декілька років після Німецької імперії, раніше інших країн13. Тобто АвстроУгорщина фактично стала провідною країною у проведенні соціальних реформ, що дозволило забезпечити стабільний економічний розвиток та зміцнити позиції влади на міжнародній арені.

При цьому складно стверджувати, що інші держави відставали у питаннях розв'язання проблем медичного забезпечення. Інші країни світу також поступово розширювали права робітників. У зв'язку з цим в Центральній Европі система медичного страхування почала діяти з середині XIX ст.

Слід зауважити, що фактори, які вплинули на становлення системи медичного страхування, як частини медико-правових відносин, мали свої «західноукраїнські» економічні особливості.

У 1852 р. в Австро-Угорській державі було прийнято закон «Про товариства», який дозволяв здійснювати діяльність у різних сферах господарства, в тому числі реєструвати страхові товариства 14 . Завдяки цьому нормативному акту, по-перше, було створено умови для власників

13 Фуртак I. I. Історичні аспекти державного управління впровадженням страхової медицини в Україні [Текст] / I. І. Фуртак // Ефективність державного управління: збірн. наук. праць. - 2010. - Вип. 25 - С. 72.

14 Цъсарскій патентъ зъ дня 26. Листопада 1852, дъятельный для цълого объєму Державы изъятно Войскового Пограничья, котрымъ розпоряджаютъ ся новіи опредъленія взглядомъ стоваришеній (законъ о стоваришеніяхъ) // Общій законовъ дєржавныхъ и Правительства въстникъ для Цъсарства Аустріи. - Рочникъ 1852. Втора часть объимає XLI-LXXIX части (числа 134-265), выданіи въ мъсяцяхъ Липцю до Грудня 1852. - Въдень : Зъ ц. к. надворнои и статскои тискарнъ. - 1852. - С. 1110. 
підприємств, які зрозуміли необхідність розширення діяльності. По-друге, надано гарантії розвитку страхової сфери, що мало збільшити товариства та диверсифікувати послуги. Даний закон поклав початок становленню галузі страхування.

Наступні нормативні положення приймалися відповідно до даного закону, розповсюджуючи норми про соціальне забезпечення робітників на різні сфери суспільного життя.

Так, у 1892 р. було прийнято закон про каси взаємодопомоги. Він визначав правовий статус товариств та надавав можливість працівникам страхувати власне життя та здоров'я. Це викликало інтерес фабрикантів, оскільки обов'язок забезпечення хворих покладався на відповідні каси, що економило кошти підприємств. Тому керівництво заводів намагалося розповсюдити серед робітників законодавчі нововведення. Даним законом встановлювався контроль за функціонуванням кас взаємодопомоги. Страхові товариства надавали інформацію про діяльність правоохоронним органам та відомствам крайової влади ${ }^{15}$. Подібна практика була відома у країнах Центральної Свропи. Міністерство внутрішніх справ брало на себе зобов'язання із забезпечення лікарень як частину функцій із охорони порядку. Місцеві органи влади вели реєстр страхових товариств певного воєводства та мали інформацію про кількість підприємств, розташованих на підвідомчій території. Чиновники безпосередньо брали участь у розв'язанні питань соціального забезпечення робітників, що дозволяло реалізувати на практиці законодавчі положення.

Контроль за страхуванням робітників здійснювався у декількох напрямах. По-перше, керівники заводів були зацікавлені у тому, щоб надання медичної допомоги мало загальнообов'язковий характер. Це давало змогу координувати діяльність підприємств із касами взаємодопомоги у частині соціального забезпечення працівників. По-друге, органи внутрішніх справ здійснювали нагляд за функціонуванням лікарень та мали відомості про характер захворювання пацієнтів. Враховуючи той факт, що дане відомство користувалося популярністю у суспільстві, здійснення контролю саме правоохоронними органами позитивно впливало на діяльність закладів охорони здоров' я, які відчували державну підтримку. Усвідомлення факту, що діяльність страхових органів гарантована владою, позитивно впливало на

15 Законь зъ дня 16 Липця 1892, дотычно регистрованыхъ касъ помочныхъ // Въстникъ законовъ державныхъ для королевствъ и краевъ въ державной думъ заступленыхъ. - Рочникъ 1892. - № 202. - Ч. LXXII. - Въдень: Тискомъ цъсарскокоролевской надворнои и статскои печатнъ. -1892. - С. 902. 
збільшення кількості учасників кас взаємодопомоги. По-третє, крайові органи влади вели реєстр страхових товариств і пацієнтів лікарень. Це дозволяло ретельно дотримуватись основ законодавства про медичне право, із боку як кас взаємодопомоги, так і керівників підприємств. Взаємопов'язаність місцевої влади із центральними органами державного управління надавала можливість забезпечити виконання нормативних положень та вчасно фіксувати правопорушення, що визначало особливості розвитку соціального законодавства на цьому етапі.

Із розвитком системи страхування на території Австро-Угорщини з' явилася необхідність більш детально врегулювати цю сферу та визначити правову базу функціонування вказаної діяльності. Тому 5 березня 1896 р. було видане розпорядження міністерств внутрішніх справ, юстиції, торгівлі та фінансів. Даний нормативний акт визначав порядок створення та припинення товариств. Прийняття такого розпорядження стало логічним продовженням започаткованих реформ на території імперії, що обумовило відкриття на західноукраїнських землях товариств, які пропонували послуги із страхування життя та здоров'я. Так, було створено товариство «Дністер», представництва якого відкрилися у Галичині та на Буковині. Дане підприємство здійснювало різні види страхування, що дозволило у 1902 р. видати страхових полісів на суму 116069.877 крон ${ }^{16}$. Це означало, що громадськість була зацікавлена у подібних послугах та намагалася скористуватися наданими державою гарантіями захисту їх інтересів.

На підтвердження такої тези можна вказати, що на початку XX ст. спостерігається збільшення страхових товариств. Так, у 1911 р. було створене товариство «Карпатія», яке надавало послуги по страхуванню життя і здоров’ я. Дана послуга тільки почала розповсюджуватися на західноукраїнських землях та отримала позитивні результати, оскільки через рік після відкриття реалізувала 1260 полісів на суму 3972 тис. крон. При цьому особливою популярністю компанія користувалася серед представників інтелігенції, таких як вчителі, адвокати, лікарі тощо ${ }^{17}$. Це можна пояснити потребою просвітніх

16 Товариства асекурацийні // Товариш. Ілюстрований калєндар товариства «Просьвіта» на рік переступний 1904. - Річник III. - Львів : Друкарня Наукового Товариства імени Шевченка під зарядом К. Беднарского. - 1903. - с. 52.

17 Гавліч І. Б. Роль страхових товариств "Дністра" i "Карпатії" у кредитному забезпеченні кооперативного руху Східної Галичини (кінець XIX - початок XX ст.) [Текст] / I. Б. Гавліч // Наукові записки Тернопільського національного 
верств населення використовувати новаторські зміни та брати участь у нововведеннях, запропонованих державою. Хоча слід зауважити, що поступово бажання отримати страховий поліс розповсюдилося на робітників та селян, які також ставали членами товариств ${ }^{18}$.

Страхові товариства Австро-Угорщини було створено для здійснення послуг переважно майнового страхування, оскільки проблеми збереження житла від пожеж або захист від неврожаю були першочерговими питаннями для європейського суспільства на початку XX ст. Каси взаємодопомоги брали зобов'язання із страхування хворих із гарантією надання медичного забезпечення. Діяльність кас мала популярність серед усієї громадськості незалежно від професії та соціального стану. Подібні органи було створено переважно для страхування робітників від нещасних випадків, праця яких була пов'язана із загрозою життю та здоров'ю. У першу чергу були застраховані працівники державної залізниці. Сума страхових зборів у 1909 р. склала 49.371.524 крон. В 1910 р. - 55.354.894 крон. При цьому витрати на страхування від нещасних випадків у 1910 р. склали суму у 58.070.743 крон проти 57.534.714 у 1909. Прибуток страхових товариств становив у 1910 р. 5.210 .669 крон проти 1.106 .226 у 1909 p. ${ }^{19}$.

Впровадження системи страхування робітників дало позитивний результат. По-перше, робітники та члени їх сімей отримали можливість користуватися якісною медичною допомогою. Це знизило напруженість у суспільстві, що не довіряло уряду, бо люди відчували порушення їх соціальних прав посадовими особами. Із розвитком медичного страхування зросла репутація підприємств промисловості, оскільки виконання трудових обов' язків за важких умов праці компенсувалося належною оплатою та гарантіями соціального забезпечення. По-друге, каси взаємодопомоги завдяки внескам працівників могли збільшувати власний бюджет, що вплинуло на їх фінансову спроможність. Це створило умови для розширення мережі товариств на території держави.

Отже, процес загального соціально-економічного реформування обумовив

педагогічного університету ім. В. Гнатюка. Серія : історія. - Тернопіль, 2011. - Вип. 1. : у 2 ч., ч. 2 - С. 17.

18 Рускі Товариства господарско-заробкові, кредитні і асекурацийні // Товариш. Ілюстрований калєндар товариства «Просьвіта» на рік звичайний 1905. - Р. IV. - Львів : Друкарня Наукового Товариства імени Шевченка під зарядом К. Беднарского. - 1904. 19 Социальное страхование. Обязательное страхование рабочих в 1910 г. в Австрии от несчастных случаев / С Сраховое обозрение. - 1912. - Январь. - С. 25. 
становлення медичного страхування на українських землях АвстроУгорщини. Залучення внутрішніх i зовнішніх інвестицій допомогло покращити умови надання медичної допомоги населенню, відобразилося на отриманні прибутку товариств та створило можливості для поповнення державного бюджету. Крім того, налагодження контактів із іноземними компаніями дозволило зміцнити позиції країни на міжнародній арені, оскільки європейським партнерам було доведено, що правляча династія турботу про власних підданих вважає першочерговим завданням.

Цікавим видається той факт, що австрійська модель передбачала переважно здійснення виплат у разі настання нещасного випадку, на відміну від інших держав, які пропонували хворому безоплатне лікування, утримання в установах охорони здоров'я за рахунок підприємства та ін. У разі отримання травми працівник мав право на виплату пенсії - до 60 відсотків заробітку ${ }^{20}$. Австрійська держава намагалася реалізувати право на соціальне забезпечення через сплату грошової компенсації, у разі настання страхового випадку. 3 одного боку, така система мала переваги, оскільки підприємство звільнялось від безпосередньої участі у наданні медичної допомоги, а робітник міг самостійно обирати сприятливий заклад охорони здоров'я. 3 іншого, функціонування лікарень при заводах, гарантувало безоплатне лікування та підіймало авторитет підприємства.

Керівництво заводів давало усвідомити готовність не тільки фінансово компенсувати шкоду, пов'язану із ушкодженням здоров'я, але й забезпечити безоплатну медичну допомогу, повністю реалізувавши право робітника на соціальний захист. При цьому робітники мали право подавати скарги до третейських судів та інших органів влади, але не могли повністю захистити свої права. У зв'язку із цим на початку XX ст. збільшилася кількість мітингів і страйків. Працівники та селяни вимагали покращення умов праці та надання якісної медичної допомоги.

Реформа, яка почалася наприкінці XIX ст., потребувала змін. Соціальна напруженість зросла у зв' язку із початком Першої світової війни. Землі Західної України стали лінією фронту, що унеможливлювало реалізацію соціальних положень. За умови ведення бойових дій господарську діяльність було повністю переорієнтовано на потреби збройних сил.

Слід зазначити, що Австро-Угорщина у питаннях запровадження медичного страхування користувалася зарубіжним досвідом та орієнтувалася

20 Социальное страхование в Европе: согласно современному законодательству различных государств / / Страховое обозрение. - 1912. - Декабрь. - С. 817. 
на німецьке законодавство, яке вважалося прогресивним. Це дозволяло проаналізувати позитивні та негативні риси законодавчої моделі й отримати власний досвід, на підставі якого уряд міг вносити своєчасні зміни до відповідних нормативних актів. Соціальне страхування в Австро-Угорщині розповсюджувалося на робітників і селян, тобто охоплювало більше верств населення, та надавало медичне забезпечення працівникам підприємств Західної України. Соціальні програми Австро-Угорщини розповсюджувалися на всю територію імперії, що дозволяє стверджувати про високий рівень піклування про власне населення з боку уряду.

Разом із тим, законодавчо закріплена система страхування здоров'я в Австро-Угорщині мала недоліки на практиці.

Можливість декільком контролюючим органам здійснювати перевірки дотримання нормативних положень призводило до нехтування посадовими особами своїх обов'язків. Керівництво заводів було зацікавлене у зменшенні внесків до кас взаємодопомоги та звільненні від виплат за страхуванням у разі настання нещасних випадків. Представники муніципальної влади могли досягти домовленості із фабрикантами та не сприяти захисту працівників від свавілля власників підприємств. Це породжувало корупиійні схеми та призводило до неналежного функиіонування системи соціального забезпечення.

Система страхування в Австро-Угорщині могла надати гарантії соціального забезпечення представникам різних верств населення. При цьому жителі західноукраїнських земель мали право брати участь у діяльності кас взаємодопомоги та отримували грошову компенсацію у разі настання нещасного випадку. Наявність соціальної захищеності у суспільстві позитивно відобразилася на благополуччі громадян та обумовила створення перспектив для розвитку системи якісної медичної допомоги. Але неналежне дотримання законодавчих положень фрабрикантами та посадовими особами, у сукупності із масштабними бойовими діями 1914-1918 рр., заважали процесу реформування сфери медичного страхування та вплинули на повний економічний занепад крайни. Це призвело до зміни суспільного ладу та розподілення земель Західної України між декількома державами.

У листопаді 1918 р. було створено Західно-Українську Народну Республіку (ЗУНР), яка включала території Західної України, що раніше входили до Австро-Угорщини. Утворення такої держави було логічним продовженням геополітичних пертурбацій попередніх століть, оскільки на території колишньої імперії розгортався збройний конфлікт між різними політичними групами. За цих умов стало можливим проголошення незалежності Галичини, 
Буковини і Закарпаття та створення представницького органу - Української Національної Ради ЗУНР на чолі із С. Петрушевичем.

Основним завданням новоствореної держави стало відтворення господарського комплексу, який було зруйновано у роки війни. За таких умов проводити політику страхування робітників було важко і недоцільно, оскільки товариства не могли забезпечити нормальне надання послуг через відсутність правопорядку. Крім того, через соціальну кризу зубожіло населення. Працівники не могли фінансово забезпечити себе та членів своїх сімей. Страхування життя та здоров'я втратило першочергове значення для суспільства. Враховуючи той факт, що нова влада намагалася визначити правовий статус держави у міжнародних відносинах, внутрішні проблеми загострювалися, економічний занепад поглиблювався, що вплинуло на нову хвилю незадоволень серед робітників підприємств. Усе це унеможливлювало введення у дію медичного страхування.

Слід зауважити, що правлячий клас новоствореної республіки намагався контролювати ситуацію та зберегти ті законодавчі переваги, які існували у минулому. Норми щодо страхування робітників від нещасних випадків продовжували діяти, але мали фіктивний характер, оскільки неспроможність робітників зробити відповідні внески заважали реалізації програм соціального забезпечення.

Ще однією причиною неможливості дотримання прав громадян став голод серед селян, який фактично означав крах усіх суспільних перетворень та державного ладу республіки. Неможливість очільників ЗУНР забезпечити населення мінімальними продуктами харчування за умов збройного конфлікту та міжнародне невизнання країнами Свропи призвели до формального керівництва урядом республікою, що унеможливлювало проведення змін у законодавчій, соціальній, медичній та інших сферах.

Із липня 1919 р. реальна влада стала належати окупаційним польським військам, які зайняли західноукраїнські землі.

Незважаючи на спроби вибороти самостійність та домогтися проведення незалежної внутрішньої та зовнішньої політики, ЗУНР не вдалося зберегти ті основи соціального захисту, які мали жителі, знаходячись під австрійською короною. Медичне страхування у сукупності із іншими елементами реформування правового статусу робітників було згорнуто внаслідок запровадження нових основ функціонування соціальної сфери, які існували в державах, що окупували території Західної України.

Слід зазначити, що за рівнем економічного розвитку Галичина знаходилася на одному із останніх місць в Європі. Проте тут кращими були умови для 
розвитку сільського господарства 21 . Незважаючи на можливості для реформування даного регіону та розширення аграрного потенціалу, що мало потягнути за собою підвищення економічного та соціального становища місцевих жителів, польський уряд не ставив завдання перетворити изі території на розвинутий ma благополучний край держави. Навпаки, землі Галичини сприймалися як сировинне джерело для промислових районів Польщі. Існувала зацікавленість у дешевій робочій силі, яка була зобов'язана працювати на промислових підприємствах.

Працівники, у свою чергу, вимагали виплати заробітної плати і належні умови праці, включаючи надання медичної допомоги. Як вказує М. Зільбельман, становище трудящих на Західній Україні було важким. Післявоєнна криза призвела до скорочення виробництва, що негативно відобразилося на рівні безробіття ${ }^{22}$. Неможливість створити робочі місця та відсутність дій із соціального забезпечення працюючих громадян викликали численні страйки, внаслідок чого почалися збої на підприємствах важкої промисловості. Проблеми існували і в аграрній галузі, яка не розвивалася, а селяни не могли сприятливо реалізувати власну продукцію.

Земельну реформу під тиском уряду на початку 20-х рр. XX ст. було спрямовано на збільшення числа польського населення серед мешканців Західної України. Фактично було проведено колонізацію, наслідком якої стало обмеження прав громадян украӥнського походження, оскільки вони не мали коштів на купівлю земельної ділянки. За таких умов складно було проводити реформу соціального забезпечення та впроваджувати основи медичного страхування. Подібні послуги мають місце лише у певних конкретних районах із фінансовою спроможністю населення.

Усім відомо: особи готові страхувати власне життя та здоров'я лише тоді, коли мають стабільний заробіток та гарантії надання першочергової медичної допомоги. У протилежному випадку, дана сфера не користується популярністю у суспільстві. Слід зауважити, що страхові товариства діяли на території Польської Республіки та були розповсюджені на землях Західної України. Так, у м. Львів розміщувалися компанії «Варрант», «Патріа», «П'яст»,

21 Савченко О. Регіональна політика польської влади стосовно західноукраїнських земель у 20-30-х рр. XX ст. та ऑї наслідки для соціально-економічного становища краю[Текст] / О. Савченко // Південний архів. Історичні науки. - Харків: Вид-во ХДУ, 2010. - Вип. ХXXI-XXXII. - С. 237.

22 Зільбельман М.Й. Революційна боротьба трудящих Західної України (1924-1928 рр.) [Текст] / М.Й. Зільбельман. - Львів: Вид-во Львівськ. ун-ту -1968. С. 46. 
«Веста» та ін. ${ }^{23}$. Вони пропонували укладати договори на страхування життя, на випадок хвороби. Але у таких угодах були зацікавлені заможні громадяни, такі як промисловці, землевласники. Робітники та селяни, внаслідок політики уряду, який не ставив за мету соціальний розвиток даних територій, не могли у повному обсязі користуватися подібними послугами.

При цьому, слід зазначити, що галузь охорони здоров'я успішно функціонувала на західноукраїнських землях. Відбувалася розбудова лікарень, які надавали безоплатну допомогу малозабезпеченим громадянам i вели боротьбу з інфекційними хворобами. Було видано декрет про обов'язкове забезпечення на випадок хвороби, відповідно до якого в усіх повітах створювалися каси хворих. Особи, які займалися найманою працею, були залучені до відповідних кас та здійснювали відрахування із заробітної плати 24. Створення таких органів сприяло розвитку системи медичного страхування, яке не залежало від рішень керівництва підприємств та відповідало інтересам як працівників, так і роботодавців. Це дало можливість забезпечити лікарською допомогою населення, що сприяло реформуванню соціальної сфери у цілому. Але практичне втілення законодавства щодо кас хворих мало недоліки, які у першу чергу відображалися на робітниках західноукраїнських земель, зайнятих у сільському господарстві. Внаслідок тяжкого економічного становища селяни не мали змоги відраховувати відповідні внески, що унеможливлювало поширення програм страхування на сільське населення регіону. Також слід вказати на порушення законодавства у сфері соціального забезпечення, оскільки існували випадки заперечення факту наявності нещасного випадку, що тягло за собою відмову у наданні медичної допомоги робітникам. Усе це призводило до непорозумінь між трудовими колективами і власниками підприємств i не дозволяло у повному обсязі реформувати соціальну сферу.

У зв'язку із цим, галузь медичного права, включаючи страхування практично не розвивалася, що негативно впливало на реалізацію програм соціального забезпечення та відображалося на добробуті населення.

У 1939 р. розпочалася війна, внаслідок якої Польщу було розділено між Німеччиною та СРСР. Усі реформи уряду Другої Речі Посполитої було скасовано, а землі Галичини увійшли до складу Української Радянської

23 Хонігсман Я. Економіка Західної України під гнітом Іноземного капіталу (19181939) [Текст] / Я. Хонігсман. - Львів: Каменяр, 1964. С. 103.

24 Давибіда Л. І. Каси хворих у Галичині (1919-1933 рр.): історичний аспект / Л. I. Давибіда / / Галичина. - 2013. - Ч. 22-23. - С. 233. 
Соціалістичної Республіки.

Дослідивши розвиток медичного страхування українських земель у складі Польщі, доцільно перейти до розгляду соціального законодавства на територія Буковини й Хотинщини, яка у листопаді 1918 р. була зайнята румунськими збройними силами, а згодом включена до Королівства Румунія. Під час бойових дій вони перетворилися на лінію фронту. У зв'язку із цим, для розвитку у складі Румунії потрібно було провести процес адаптації законодавства цих земель до відповідності нормативному базису королівства. Складність полягала у тому, що інші держави (Польща, Чехословаччина), до яких було включено території Західної України, утворились згідно із результатами війни і на початку 1920-х рр. будували власну нормативну основу «з нуля». Румунія ж, у свою чергу, була на момент розгортання бойових дій суверенною країною понад тридцять років. За цей період сформувалися необхідні правові інститути. Землі Буковини та Хотинщини мали увійти у румунську систему законодавства, поступово відновлюючи економічний розвиток регіону після війни. Разом з тим, потрібно зауважити, що Перша світова війна негативно вплинула на розвиток регіону, адже практично знищила його потенціал. Це вплинуло на зростання безробіття, що призводило до порушення трудового законодавства. У такому випадку працівники не могли знайти постійний заробіток та були готові працювати ненормований робочий день. Подібна ситуація склалася і в аграрній сфері. Для сільського господарства був характерним низький рівень розвитку, що унеможливлювало його ведення. Фактично це означало створення перешкод із боку держави для сприятливого здійснення господарської діяльності. Слід зазначити, що система медичного страхування може функціонувати тільки у сукупності із реформою галузі охорони здоров'я, оскільки лікарні не мали змоги вчасно проводити профілактичні заходи із метою запобігання епідеміям. Такий стан речей не міг дозволити нормально функціонувати системі соціального захисту, що поглиблювало кризу у суспільстві та незадоволення чинною владою.

Незважаючи на той факт, що Буковина та Хотинщина були частиною Румунії понад двадцять років, населення даних територій не змогло повністю користуватися соціальними правами. Низьке економічне становище регіону не дозволило належним чином застосувати законодавство про медичне страхування. У 1940 р. дані території зайняли радянські війська, внаслідок чого відбулось приєднання Буковини та Хотинщини до складу СРСР, що обумовило скасування соціальних реформ, які проводилися румунським урядом.

Виявивши особливості розвитку медичного страхування на українських землях, що входили до складу Польщі та Румунії, слід дослідити соціальний 
стан земель Закарпаття. Їх було включено до складу Чехословацької республіки на правах автономії, відповідно до рішень Паризької мирної конференції 1919 p.

В. Лемак зазначає, що введення положення про автономний статус Закарпаття до тексту Конституції Чехословаччини повинно було засвідчити входження Підкарпатської Русі до їі складу на федеральниз засадах 25 . Це дозволяло місцевим органам влади самостійно визначати основи розвитку регіону, відповідно до інтересів держави.

Закарпаття, як і інші українські землі, знаходилося у кризовому стані після війни, що відобразилося на сільському господарстві та у зниженні виробництва й споживання продовольчої продукції. Це негативно впливало на соціальне становище робітників і селянства, яке не могло нормально працювати, отримувати прибуток. Уряд намагався запровадити реформу соціального забезпечення. Але законодавча база часів Австро-Угорщини не могла остаточно бути втіленою у нових реаліях, бо система медичного страхування функціонує за умов економічного добробуту громадян та фінансової стабільності держави, коли є можливість виділити бюджетні кошти на реформування соціального забезпечення. Впродовж 20-х рр. XX ст. уряд Чехословаччини пропонував зміни до чинних актів, практичне застосування яких було складним за умов наявної економічної кризи. Також на території Закарпаття діяли закони колишньої Угорщини, які визначали порядок ведення господарської діялності. На основі даної тези можливе припущення, щзо законодавство Підкарпатської Русі було більш розвинутим у порівнянні із іншими регіонами республіки. Але таке твердження є помилковим, оскільки, по-перше, влада Чехословаччини проводила реформування нормативної сфери, намагаючись відіитти від канонів імперської Австріі. По-друге, соиіальне законодавство вважається розвинутим, коли відбувається прогрес у забезпеченні населення відповідними правами. За скрутного економічного становища неможливо стверджувати, щзо законодавчі положення відповідали потребам мешканців регіону.

Однією із форм провадження господарської діяльності у різних сферах суспільного життя були картелі. Метою цих організацій є об'єднання підприємців для збуту товару. Це дозволяло закріпитися на ринку та бути конкурентоспроможним у відносинах із споживачами, які проявляли інтерес до таких новаторських змін та були зацікавлені в укладанні угод про

25 Лемак В. Конституційно-правовий статус Підкарпатської Русі та проблеми його реалізації[Текст] / В. Лемак // Державно-правовий статус Закарпаття в складі Чехословаччини у 1919-1945 роках: матеріали наук. конф. - Ужгород, 1996. - С. 19. 
страхування життя та здоров'я.

На початку 1930-х рр. на території Європи почалася економічна криза, яка вплинула на фінансове положення Чехословаччини. Робітники та селяни масово втрачали роботу. Це негативно відбилося на соціальних програмах, які втрачали актуальність, оскільки не становили інтересу для підприємців та робітників.

Економічна криза обумовила внутрішні протиріччя, які вилилися у мітинги та страйки. Намагаючись зменшити рівень напруженості, у жовтні 1938 р. парламент республіки прийняв нову Конституцію. Даний нормативний акт встановлював широкі права Підкарпатської Русі, яка тепер отримала назву Карпатська Україна, та наголошував на ії автономії у складі Чехословаччини. Такі законодавчі зміни не принесли суттєвих результатів, оскільки на той час виникали протиріччя на міжнародній арені, що призводили до локальних збройних конфліктів. Чехословаччина намагалася знайти союзників у зовнішньополітичних відносинах. Крім того, економічна криза негативно вплинула на промисловий розвиток держави та стимулювала українські національно-державотворчі процеси, які торкнулися усього закарпатського регіону.

15 березня 1939 р. Карпатська Україна проголосила незалежність, що передбачало самостійне вирішення усіх питань економічного та соціального характеру. Це мало призвести до розробки та прийняття власної нормативної бази щодо медичного страхування. Але вказаний крок мав переважно політичне значення, оскільки новостворене державне утворення не мало ресурсів та планів поступового реформування сочіальної сорери із метою забезпечення добробуту громадян. Як наслідок, на землях Закарпаття відбулося поглиблення суспільних протиріч, що унеможливлювало проведення реформ. Слід додати, що Карпатська Україна як незалежна держава проіснувала короткий строк та була остаточно окупована угорськими військами 17 березня 1939 р. Це означало згортання усіх програм розвитку медичного страхування для мешканців Підкарпатської Русі, територія якої стала частиною Угорщини.

Під час Другої світової війни, землі Галичини, Буковини, Закарпаття було розподілено між сторонами конфлікту, що не дозволяло практично втілювати нормативні положення щодо медичного страхування громадян.

Становлення медичних правовідносин було обумовлено залученням робочої сили до роботи на промислових підприємствах, що привело до розвитку соціального законодавства. Страхування виступало гарантією реалізації прав працівників на медичну допомогу. Тому, страхування здоров'я стало частиною всього комплексу відносин медичного права. 
На підставі викладеного можна зазначити, що землі Західної України рецепіювали норми законодавства країн, до яких входили. Розвиток медичного страхування на західноукраїнських землях визначався нормативними актами Австро-Угорської імперії. Медична допомога гарантувалася робітникам підприємств і селянам, що сприяло розвитку медичного права в цілому. Соціальні програми у Австро-Угорщині охоплювали всю територію імперії і були згорнуті із розпадом держави.

Уряди Польщі, Румунії, Чехословаччини не були зацікавлені у становленні вказаних територій, що відобразилося на програмах соціального забезпечення, які практично не розвивалися. Разом із тим, були спроби впровадити медичне страхування для робітників і селян. Для цього страхові компанії та фабричні каси поширили свою діяльність на західноукраїнські землі. Економічний занепад західноукраїнських регіонів і недоцільна політика керівництва країн, до складу яких входили дані землі, заважали громадянам отримати належне забезпечення соціальних прав.

PhD in Law Arsen Terovanesov (Kharkiv, Ukraine)

The Development of Medical Law in the Lands of Western Ukraine in the First Half of XX century (Insurance Aspect)

The paper studies the features of the development of medical law at the beginning of the twentieth century. It has been established that during this period, preconditions appeared, which, together with the norms of social legislation, legal acts regulating insurance relations, were transformed into medical law. The necessity of studying health insurance as an integral part of medical law is argued. The article analyzes the legislation of the Western Ukrainian lands that were part of AustriaHungary, which regulated the basic legal relations for the protection of the social rights of citizens, focusing on the positive experience of European states. It was found that the development of health insurance was facilitated by the reform of the industrial sector, agriculture, as well as the successful construction of railways, which required not only financial investments, but also the involvement of labour. The historical and legal aspect of the development of health insurance on the lands of Western Ukraine, which were part of Poland, Romania, Czechoslovakia at the beginning of the 20th century, is considered. It was found that health insurance programs existed, but did not gain popularity due to poverty and social insecurity of the population.

Key words: Medical Law, Medical Insurance, Lands of Western Ukraine, HistoricalLegal Aspect, Social Legislation, Health Insurance. 
Кандидат юридических наук Арсен Терованесов (Харьков, Украина) Развитие медицинского права на землях Западной Украины в начале XX в. (аспект страхования)

В работе исследованы особенности развития медицинского права в начале XX века. Установлено, что в этот период появились предпосылки, которые, в совокупности с нормами социального законодательства, правовыми актами, регулирующими отношения страхования, трансформировались в медицинское право. Аргументирована необходимость изучения страхования здоровья как неотъемлемой части медицинского права. Проанализировано законодательство западно-украинских земель, входивших в состав АвстроВенгрии, которое регулировало основные правоотношения по защите социальных прав граждан, ориентируясь на позитивный опыт европейских государств. Установлено, что развитию медицинского страхования способствовало реформирование промышленной сферы, сельского хозяйства, а также успешное строительство железных дорог, что требовало не только финансовых вложений, но и привлечения рабочей силы. Рассмотрен историко-правовой аспект развития медицинского страхования на землях Западной Украины, входивших в начале XX столетия в состав Польши, Румынии, Чехословакии. Установлено, что программы медицинского страхования существовали, однако не пробрели популярности в силу бедности и социальной незащищенности населения.

Ключевые слова: медицинское право, медицинское страхование, земли Западной Украины, историко-правовой аспект, социальное законодательство.

Кандидат юридичних наук Арсен Терованесов (Харків, Україна)

Розвиток медичного права на землях Західної України на початку XX ст. (аспект страхування)

У роботі досліджені особливості розвитку медичного права початку $\mathrm{XX}$ століття. Встановлено, що в цей період з' явилися передумови, які, в сукупності 3 нормами соціального законодавства, правовими актами, що регулюють відносини страхування, трансформувалися в медичне право. Аргументовано необхідність вивчення страхування здоров' я як невід'ємної частини медичного права. Проаналізовано законодавство західно-українських земель, що входили до складу Австро-Угорщини, яке регулювало основні правовідносини щодо захисту соціальних прав громадян, орієнтуючись на позитивний досвід європейських держав. Встановлено, що розвитку медичного страхування сприяло реформування промислової сфери, сільського господарства, а також успішне будівництво залізниць, що вимагало не тільки фінансових вкладень, а 
й залучення робочої сили. Розглянуто історико-правовий аспект розвитку медичного страхування на землях Західної України, що входили на початку XX століття до складу Польщі, Румунії, Чехословаччини. Встановлено, що програми медичного страхування існували, проте не набули популярності через бідність і соціальну незахищеність населення.

Ключові слова: медичне право, медичне страхування, землі Західної України, історико-правовий аспект, соціальне законодавство.

* Терованесов Арсен Михайлович - кандидат юридичних наук, дослідник сфери медичного права та проблем медичного страхування (м. Харків, Україна). E-mail: arsterov@gmail.com. 